contains a number of interesting papers. The paper by de Haas and his co-workers on the attainment of very low temperatures by adiabatic magnetic changes is referred to in our Research Items (p. 181). Druyvesteyn describes experiments on the lowvoltage arc in sodium vapour. The absorption of the $D$ lines was measured in the arc and the reversal of the $D$ lines against a continuous source at variable. temperature was observed. The results show that the number of excited sodium atoms is about 12 per cent of the number of the normal atoms, and that the number of $\mathrm{Na}+$ ions is several times the number of normal atoms. The theory of light emission in gaseous discharges is discussed by W. De Groot. Van Heel describes a quartz-fluorite combination lens which is achromatic and spherically connected. It is intended for focusing light on a thermocouple with unit magnification. P. Cohen Henriquez describes a micro-apparatus for determining the dipole moment of organic solutes. The apparatus may be used with a few milligrams of material. The ratio of the lithium isotopes has been determined by intensity measurements of the fine structure of the $\mathrm{Li}$ resonance line by Ornstein, Vreeswijk and Wolfsohn. Van Kreveld describes an empirical summation law for a photographic plate exposed to light of two or more colours, and Van der Pol and Weyers describe the approximations known as Tchebycheff polynomials. The papers are in English or German, and in some cases German papers are provided with an abstract in English.

Recent Acquisitions at the British Museum (Natural History)

AMONG the recent acquisitions at the Natural History Museum the Department of Zoology has received as a donation from Mrs. Charles Buckley and Mr. Godfrey R. Buckley the mounted head of a cow of the Chartley breed of cattle. Chartley Park was formed by enclosing about 1,000 acres of the forest of Needwood in the reign of Henry III, when a number of half-wild cattle, which then roamed throughout the district, were driven in and enclosed in the Park. Two important additions have recently been made to the beetle collections in the Department of Entomology, namely the Donisthorpe collection of British Coleoptera and an Australian collection purchased from Mr. W. du Boulay. The former contains upwards of 22,000 specimens, and is of especial interest in that it is accompanied by the most complete set in existence of the numerous British insects (mainly beetles) and other arthropods that live in association with ants and are known as myrmecophiles. The du Boulay collection, which numbers only 352 specimens, consists, however, entirely of beetles actually found inhabiting ants' nests in various parts of Australia by Mr. du Boulay over a period of sixteen years. Mr. R. E. Turner, working in South Africa, has collected and presented to the Museum some 8,000 insects of various kinds, principally small bees and wasps; and from the mountains of New Guinea Miss L. E. Cheesman has collected for the Museum upwards of 18,000 specimens. Miss M. Graves, M.P., has presented to the Geological
Department some portions of the egg-shell of a small horned dinosaur, Protoceratops andrewsi. The South Australian School of Mines and Industries has presented an end-slice of a large mass $(2,520 \mathrm{lb}$.) of meteoric iron found in 1909 at Murnpeowie, South Australia, previously represented in the collection only by a cast of the whole mass.

Sunday Lectures at the British Museum (Natural History)

For the benefit of visitors to the Natural History Museum on Sunday afternoons who may wish for fuller information about the various branches of natural history than may be obtained by casual wandering through the galleries, the Trustees of the British Museum have arranged for two lectures each afternoon at 3 and 4.30 , to be given usually by a member of the scientific staff. Lectures illustrated by lantern slides will be given in the Board Room, and the remainder in one of the galleries. The opening lecture will be on Sunday, February 4, the lecturer being Capt. Guy Dollman, who will speak on the great game animals of Africa and will show a number of lantern slides. On succeeding Sundays lectures will be given by Dr. W. E. Swinton on earthquakes, Mr. Maurice Burton on seashore animals (both in the Board Room), and Mr. J. R. Norman on the Fish Gallery. Admission to the lectures is free.

THE Department of Botany of the Natural History Museum has received a bequest of the herbarium of the late Ashley H. Maude. The specimens are well mounted on about 5,000 sheets and are in good condition, contained in four cabinets. They are chiefly European but there are also collections from Algeria, Cape Colony and the Canary Islands. The Godman Trustees have presented 534 specimens of flowering plants collected by Mr. F. Ludlow and Capt. G. Sherriff in Bhutan. The area traversed is one which is not very well known botanically and as each 'number' comprises a good series of welldried plants the collection is of great value. A number of seeds were also collected, and these have been distributed. This year's collecting season in Nepal was ruined by the monsoon and consequently only fourteen specimens were collected by Prof. K. Sharma. These were presented to His Majesty the King and placed by him on loan in the Department of Botany. Although the number is small it includes several very important horticultural plants.

\section{Empire Museums and the Carnegie Corporation}

IT is gratifying to learn (from the December number of the Museums Journal) that the Carnegie Corporation has decided to grant substantial sums for the development of the museums of the Empire, following upon the Empire Survey of Museums, to which reference has been made in these notes. Already grants totalling 50,000 dollars have been made in Canada, and it has just been made known that similar sums have been set aside for South Africa, Australia and New Zealand. These will be administered by local committees. In addition to the 200,000 dollars thus earmarked, the Carnegie Corporation has also decided to appropriate 63,000 
dollars to the Museums Association for a programme of museum development in Newfoundland, Southern Rhodesia and the Colonies.

\section{A Direct Reading Universal Drawing Compass}

Mr. Thorold, 20, Rathbone Place, W.1, sends us particulars of a new instrument which is a combination of scale and compass. The compass points travel on a beam carrying interchangeable scales. The two points terminate in movable heads on the beam which are adjustable, one possessing a micrometer. The instrument is also supplied with calliper points for external and internal measurements. The maker claims that great accuracy is obtainable, and for fine drawing in the field of physical science and engineering the invention seems likely to be valuable. The cost of the instrument is $\mathfrak{E 7} 7 \mathrm{~s}$.

\section{Austrian Ethnographical Expedition to West Africa}

AN expedition, of which Dr. Ralph Elber, of the Institute of Egyptology and African Studies, is the leader, left Vienna, according to a communication issued by the Reichszentrale für Wissenschaftliche Berichterstattung, Berlin, early in January for Sierra Leone, whence it will proceed to Liberia for the purpose of exploring the interior of the country and observing the little-known tribes of that region. Special attention will be given to the study of the religious and magical beliefs of the tribes and their languages, which are virtually unknown. The results of this expedition should be of special interest in view of present lack of knowledge of the area, its inhabitants and natural history. It is also hoped to add to the map particulars of one of the last uncharted areas of Africa.

\section{Pittsburgh Award of the American Chemical Society}

The Pittsburgh Section of the American Chemical Society has selected Dr. Ralph E. Hall, director of the Hall Laboratories, Inc., Pittsburgh, Pa., as the recipient of the 1933 (the first) Pittsburgh Award. This honour, which will be conferred on Dr. Hall at the sectional meeting on February 15, is in recognition of his distinguished service to chemistry and humanity, particularly his contributions to the fundamental knowledge of boiler-water reactions and their applications to the practical solution of boilerwater problems, his discoveries and technical accomplishments in the beneficiation and conditioning of water for industrial and domestic use, and his developments in the production of chemicals for these purposes. The Pittsburgh Award is represented by a plaque of gold, on which the relation of chemistry to industry is symbolised.

\section{Announcements}

Sir William Larke, K.B.E., Director of the National Federation of Iron and Steel Manufacturers ; Prof. Edward Mellanby, F.R.S., Secretary of the Medical Research Council ; and Mr. Leonard Woolley, Director of the Joint Expedition of the British Museum and of the Museum of the University of Pennsylvania to Mesopotamia, have been elected members of the Athenæum under the provisions of Rule II of the club, which empowers the annual election by the committee of a certain number of persons of distinguished eminence in science, literature, the arts or for public service.

Sir Arthur Eddington will deliver the Rickman Godlee lecture at University College, Gower Street, London, W.C.1, on Friday, February 16, at 5.30 p.m. The subject of Sir Arthur's lecture will be: "The Constitution of the Stars". The lecture will be open to the public.

Prof. A. Zimmers, Montague Burton Professor of International Relations in the University of Oxford, is giving a course of six lectures (Muirhead Lectures in Social Philosophy) at the University of Birmingham on Thursdays, beginning on February 1, on "Britain and the World Crisis".

Mrss Nina Symington, daughter of the late Prof. Symington of Belfast, has bequeathed the residue of her estate, amounting to some $£ 9,000$, to be known as the Johnson Symington Memorial bequest, to the Anatomical Society of Great Britain and Ireland for anatomical research.

THE Council of the Institution of Naval Architects has awarded the Gold Medal for the year 1933 to Eng.-Capt. S. R. Dight, for his paper on "Naval Water-Tube Boilers. Experiments and Shop Trials"; and the premium to Dr. George Hughes, of the William Froude Laboratory, for his paper on "The Effect of Wind on Ship Performance".

Aprurcations are invited for the following appointments, on or before the dates mentioned :-A chemical assistant to the advisory chemist in the Department of Agriculture, University of Cambridge - The Secretary, School of Agriculture, Cambridge (Feb. 10). A junior assistant (chemist) in the Royal Gunpowder Factory, Waltham Abbey-The Principal Clerk, Central Office, Royal Gunpowder and Small Arms Factories, Enfield Lock, Middlesex (Feb. 10). A head of the Department of Civil Engineering and Building, and a head of the Science Department in the Lester School and Institute, Shanghai-Messrs. Viney, Price and Goodyear, Empire House, St. Martin's-le-Grand, London, E.C.1 (Feb. 20). A director of the University School of Librarianship at University College, London-The Academic Registrar, University of London, S.W.7 (March 1). A University lecturer in moral science in the University of Cambridge-The Secretary of the Faculty Board of Moral Science, King's College, Cambridge (March 1). A University lecturer in forestry in the Department of Agriculture of the University of Cambridge-The Secretary, School of Agriculture, Cambridge (April 14). A keeper of the Museum at the Victoria University of Manchester-The Registrar (April 30). A research assistant (male) in the Cancer Research Department of the Westminster Hospital, Broad Sanctuary, London, S.W.1-The Secretary. A registration officer and statistician, and a finance officer and accountant for the Potato Marketing Board-The Secretary, Potato Marketing Board, 45 Bedford Square, London, W.C.1. 